\title{
Impact of Clinical Pharmacy Services in Care of Patients with Cardiovascular Diseases: [A Prospective Study]
}

\author{
Mohammed Ashfaq Hussain ${ }^{1 *}$, Asra Yasmeen², Ruqsana Begum², Mairah Siddiqua² and Rumana Tabassum² \\ ${ }^{1}$ Assistant Professor, Department of Pharmacy Practice, Sultan-Ul-Uloom College of Pharmacy, India \\ ${ }^{2}$ Department of Pharmacy Practice, Sultan-Ul-Uloom College of Pharmacy, India
}

Submission: March 28, 2019; Published: April 12, 2019

*Corresponding author: Mohammed Ashfaq Hussain, Assistant Professor, Department of Pharmacy Practice, Sultan-Ul-Uloom College of Pharmacy, Hyderabad, Telangana, India

Abstract

Aim: The main aim of this study is to is to evaluate the impact of clinical pharmacy services in care of patients with cardiovascular diseases.

Objective: This study has highlighted the clinical pharmacy services in patients with cardiovascular diseases to achieve better quality of life with Patient counselling, encouraging Medication adherence and to evaluate Medication interventions and to ensure Cost effective treatment.

Methodology: The study included all patients who had cardiovascular diseases met inclusions criteria were included. Total selective prescriptions of 248 patients were included in the study. Convenient enrolment technique was employed in which all patients in cardiological department who were selectively observed with pharmaceutical care in Aster Prime Hospital from Oct 2018 to March 2019 were enrolled.

Result: A total of 248 cases have been studied for the evaluation of the evaluated impact of clinical pharmacy services in care of patients with cardiovascular diseases at the Aster Prime Hospital Hyderabad. Commonest age range of the patients was 61-70 years. The incidence of cardiovascular diseases in 185 (75\%) were male and 63 (25\%) were female. In our study we conclude the dose management for comorbid conditions were analysed and evaluated with the utilization of high-end prescribing drugs and other preferred therapies. In our study we conclude that the STOPP/START (Screening Tool of Older Persons' Prescriptions/Screening Tool to Alert doctors to Right Treatment) was found to be most useful for reducing Drug Related causes for Patients suffering from cardiovascular diseases. In Disease Related causes for Patients suffering from cardiovascular diseases the STOPP/START tool helped to avoid catastrophic events.

Keywords: Pharmaceutical care; Quality of life; STOPP/START; Cardiovascular diseases

\section{Introduction}

Medicate treatment is a fundamental component of restorative care to anticipate, remedy and control illness. Its reason is to diminish dreariness and mortality and to extend healthrelated quality of life (HRQoL). Treatment with drugs could be a prerequisite for numerous individuals in arrange to operate well and be able to live in their claim homes as long as conceivable. In any case, issues related with medicate treatment such as pharmaceutical mistakes and antagonistic medicate occasions are visit, particularly among the elderly. It has been appeared that at slightest $5 \%$ of clinic confirmations are caused by drug-related issues; higher prevalences have ordinarily been found within the elderly populace and among psychiatric patients [1-3].

Lethal unfavorable medicate responses has been evaluated to be the seventh most common cause of passing. Hence, there's an critical require for strategies that make strides quality and security of endorsing and decrease adverse drug occasions. There's a huge potential to progress the circumstance as the larger part of drug-related affirmations to healing center has been evaluated to be preventable. Given the complexity of the method driving to pharmaceutical blunders and unfavorable sedate occasions, it is likely that intercessions for understanding and anticipating drugrelated issues got to be multifaceted [1].

\section{Drug safety issues in the elderly}

The elderly populace is consistently expanding all through most of the world. Concurring to a report from the Joined together Countries, the extent of people over 60 a long time is anticipated to reach $22 \%$ in 2050 , compared with $11 \%$ in 2009 . In Sweden, $24.7 \%$ of the populace was over 60 a long time as of now in 2009; as it were three nations within the world had a better extent of people over 60 a long time. A major challenge in connection to this statistic shift is to guarantee that sedate treatment when required within the elderly is secure and viable [4-6]. 
This can be a complex errand, particularly in patients with agerelated physiological changes, multimorbidity and polypharmacy. Numerous elderly have a number of co-morbid unremitting infections and, so, are regularly endorsed a number of diverse drugs to be utilized concurrently (known as polypharmacy). The predominance of polypharmacy has expanded amid later a long time. Polypharmacy can be legitimized in patients with different comorbidities but may too be unseemly. In any case, the chance of antagonistic medicate responses and medicate intelligent increment exponentially with the number of drugs taken. On the other hand, undertreatment or helpful disappointment may moreover happen within the elderly [7].

\section{Appropriate prescribing}

Suitable endorsing may be a common express to precise the quality of endorsing of solutions for the person quiet. In a wide sense, fitting endorsing includes a number of values, counting the wants of the persistent, the logical and technical rationale for the utilize of the pharmaceutical, and the common great that's anticipated to be inferred from the utilize of the medicine (societal and family-related). No set definition of improper endorsing has been built up, but it can be portrayed as: "the use of medications that present a noteworthy chance of an unfavorable drug-related occasion where there's prove for an similarly or more compelling but lower-risk elective treatment accessible for treating the same condition". The under-use of advantageous drugs that are clinically shown but not endorsed for nonsensical reasons may too be characterized as unseemly endorsing [8].

\section{STOPP/START Screening Tool}

The STOPP/START screening software is a tool created as portion of this venture which takes as input persistent cases and medicine histories (through GUI input or information record) and to begin with analyzes them for STOPP run the show infringement [9]. These rule-violations are displayed to the client (e.g. a drug specialist or common specialist) and the specific threats of the medicine arrange are shown.

Following the STOPP screening, the computer program decides in the event that there are any medicines which ought to be included to the medicine arrange as per the START criteria. Any increases to the medicine arrange are checked through the STOPP screening instrument to find on the off chance that the augmentations may lead to infringement of the STOPP criteria [10].

Aim

The main aim of this study is to evaluate the impact of clinical pharmacy services in care of patients with cardiovascular diseases.

\section{Objectives}

To highlight the medicine practices of drugs within the administration of both inpatient and outpatient divisions.

Our points of interest are:
- To evaluate the impact of clinical pharmacy services in care of patients with cardiovascular diseases admitted in the cardiology unit of a university-affiliated hospital.

- $\quad$ To assess the work of clinical pharmacy services in patients with cardiovascular diseases to achieve better quality of life with Patient counselling, encouraging Medication adherence and to evaluate Medication interventions and to ensure Cost effective treatment.

\section{Methodology}

\section{Study population}

The study included all patients in Cardiological department suffering from cardiovascular diseases who were selected by case reports, prescription pattern pharmaceutical care and quality of life with there literacy level during the study period.

\section{Sample size}

Sample size was convenient sampling in which all patients who had cardiovascular diseases met inclusions criteria were included. Total selective prescriptions of 248 patients were included in the study.

Results

\section{Discussion}

Table 1: Demographic data of our studied Patients.

\begin{tabular}{|c|c|c|c|}
\hline Sl.no. & \multicolumn{3}{|c|}{ Demographics } \\
\hline 1. & \multicolumn{2}{|r|}{ Age in years } & Number of patients \\
\hline & i. & $41-50$ & 42 \\
\hline & ii. & $51-60$ & 86 \\
\hline & iii. & $61-70$ & 118 \\
\hline & iv. & $71-80$ & 2 \\
\hline \multirow[t]{3}{*}{2.} & \multicolumn{2}{|r|}{ Sex } & \\
\hline & i. & Male & 185 \\
\hline & ii. & Female & 63 \\
\hline \multirow[t]{4}{*}{3.} & \multicolumn{2}{|c|}{ Body mass index in $\mathrm{Kg} / \mathrm{m}^{2}$} & \\
\hline & i. & Underweight $(<18.5)$ & 27 \\
\hline & ii. & $\begin{array}{c}\text { Normal weight (18.5 - } \\
24.9)\end{array}$ & 93 \\
\hline & iii. & Overweight $(25-29.9)$ & 128 \\
\hline
\end{tabular}

Table 2: Social History of Patients.

\begin{tabular}{|c|c|c|c|}
\hline S. no & Social history & N & \% \\
\hline 1 & Smokers & 100 & $40.32 \%$ \\
\hline 2 & Alcoholic & 45 & $18.14 \%$ \\
\hline 3 & Both smoking \& Alcohol consumption & 43 & $17.33 \%$ \\
\hline 4 & None & 60 & $24.19 \%$ \\
\hline
\end{tabular}

In the present study of 248 patients, 185 (75\%) were male and $63(25 \%)$ were female. In our study it was found that cardiovascular diseases patients were more prevalent in males than females. Evaluation of Patient characteristics showed that out of 248 patients, $26.61 \%$ were indicating for Hypertension, 


\section{Journal of Cardiology \& Cardiovascular Therapy}

$12.90 \%$ were of indicating for Ischaemic heart disease, Heart failure, Hyperlipedemic respectively. $13.70 \%$ were indicating for Myocardial infarction, 9.27\% were indicating for Stroke, $11.69 \%$ were indicating for Angina. In our study, out of 248 patients, out Table 3: Drugs prescribed in our study.

\begin{tabular}{|c|c|c|c|}
\hline S. no & Drugs prescribed & No. of Drugs & Prescription rate $(\%)$ \\
\hline 1 & Lipid lowering agents & \multicolumn{2}{|c|}{412} \\
\hline & Rosuvastatin+ Clopidogrel + Aspirin & 121 & $29.36 \%$ \\
\hline & Atorvastatin + Clopidogrel + Aspirin & 291 & $70.63 \%$ \\
\hline \multirow[t]{3}{*}{2} & Anti-atherogenics & \multicolumn{2}{|c|}{327} \\
\hline & Clopidogrel + Aspirin & 165 & $50.45 \%$ \\
\hline & Atorvastatin + Clopidogrel & 162 & $49.54 \%$ \\
\hline \multirow[t]{3}{*}{3} & Anti-Anginals & \multicolumn{2}{|c|}{521} \\
\hline & Nitroglycerine + Isosorbide & 167 & $32.05 \%$ \\
\hline & isosorbide mononitrate and hydralazine & 354 & $67.94 \%$ \\
\hline \multirow[t]{3}{*}{4} & Beta blockers & \multicolumn{2}{|c|}{647} \\
\hline & Metoprolol + Nifedipine & 194 & $29.98 \%$ \\
\hline & Hydrochlorothiazide and Metoprolol & 453 & $70.01 \%$ \\
\hline \multirow[t]{4}{*}{5} & Diuretics & \multicolumn{2}{|c|}{654} \\
\hline & Ramipril+Telmisartan + Hydrochlorthiazide & 215 & $32.87 \%$ \\
\hline & Metoprolol + Hydrochlorthiazide & 210 & $32.11 \%$ \\
\hline & Spironolactone + Furosemide & 229 & $45.58 \%$ \\
\hline \multirow[t]{3}{*}{6} & ARBs & \multicolumn{2}{|c|}{547} \\
\hline & Telmisartan +Amlodipine & 342 & $62.52 \%$ \\
\hline & Olmesartan + Hydrochlorthiazide & 205 & $37.47 \%$ \\
\hline \multirow[t]{4}{*}{7} & Miscellaneous & \multicolumn{2}{|c|}{438} \\
\hline & Amlodipine + Atorvastatin, & 167 & $38.12 \%$ \\
\hline & Amlodipine + Valsartan & 132 & $30.13 \%$ \\
\hline & Atenolol + Amlodipine & 139 & $31.73 \%$ \\
\hline
\end{tabular}

Table 4: Grouping of prescriptions as per diseases and age.

\begin{tabular}{|c|c|c|c|c|c|}
\hline Cardiovascular Diseases & 41 - 50 years of age & $51-60$ years of age & $61-70$ years of age & 71- 80 years of age & Percentages (\%) \\
\hline Hypertension & 5 & 12 & 49 & - & $26.61 \%$ \\
\hline Ischaemic heart disease & 3 & 13 & 16 & - & $12.90 \%$ \\
\hline Heart failure & 5 & 18 & 9 & - & $12.90 \%$ \\
\hline Myocardial infarction & 8 & 14 & 12 & - & $13.70 \%$ \\
\hline Stroke & 6 & 5 & 10 & 2 & $9.27 \%$ \\
\hline Hyperlipedemic & 8 & 14 & 10 & - & $12.90 \%$ \\
\hline Angina & 7 & 10 & 12 & - & $11.69 \%$ \\
\hline$N=248$ & 42 & 86 & 118 & 2 & $100 \%$ \\
\hline
\end{tabular}

Table 5: Comorbidity conditions.

\begin{tabular}{|c|c|c|}
\hline Comorbidity & No of Prescriptions & \% \\
\hline Hypertension + Ischemic Heart Disease & 98 & $16.51 \%$ \\
\hline Hypertension + Diabetes Mellitus & 42 & $2.01 \%$ \\
\hline Kidney disease & 5 & $3.22 \%$ \\
\hline Arrhythmias & 8 & $1.61 \%$ \\
\hline Respiratory Disease & 4 & $2.01 \%$ \\
\hline Anaemia & 5 & $0.80 \%$ \\
\hline GIT disorder & 2 & \\
\hline
\end{tabular}

these patients, $39.51 \%$ were suffering from Diabetes Mellitus. Other comorbid conditions were Chronic Obstructive Pulmonary Disease in $1.61 \%$, Kidney disease in $2.01 \%$ (Table 1-9) (Figure 1-10). 


\section{Journal of Cardiology \& Cardiovascular Therapy}

Table 6: Drug Related Causes.

\begin{tabular}{|c|c|c|c|}
\hline Drug Related Causes & No. of Patients & PC & Not PC \\
\hline Digoxin Intoxication & 10 & 8 & 2 \\
\hline Over-Prescribing of Antihypertensives & 30 & 26 & 4 \\
\hline Dehydration due to over Prescribing of Diuretics & 8 & 5 & 3 \\
\hline Anaemia due to Aspirin or NSAIDS & 5 & 3 & 2 \\
\hline Confusions/Fall due to sedatives, opioids, anticholergenics & 3 & 2 & 1 \\
\hline Diarrhoea due to antibiotic treatment & 5 & 4 & 1 \\
\hline Hyperkalemia & 2 & 1 & 1 \\
\hline Hypernatraemia & 3 & 2 & 1 \\
\hline Atrial Fibrillation & 15 & 12 & 3 \\
\hline Bleed due to Warfarin & 43 & 35 & 8 \\
\hline Total & 124 & 98 & 26 \\
\hline
\end{tabular}

*PC $=$ Patient Counselling

Table 7: Disease Related Causes.

\begin{tabular}{|c|c|c|c|}
\hline Disease Related Causes & No. of Patients & PC & 8 \\
\hline Smoking & 12 & 10 & 4 \\
\hline Hypertension & 13 & 25 & 3 \\
\hline Hyperlipidemia & 32 & 4 & 1 \\
\hline Chronic renal dysfunction & 5 & 24 & 4 \\
\hline Diabetes mellitus & 28 & 3 & 1 \\
\hline COPD & 4 & 8 & 2 \\
\hline Peripheral vascular disease & 10 & 10 & \\
\hline Prior Myocardial Infarction & 12 & 7 & \\
\hline Prior Percutaneous Coronary Intervention & 8 & $\mathbf{9 9}$ & \\
\hline
\end{tabular}

${ }^{*} \mathrm{PC}=$ Patient Counselling

Table 8: Screening Tool of Older Persons' Prescriptions.

\begin{tabular}{|c|c|c|c|}
\hline STOPP & No. of Patients & PC (STOPP) & Not PC(STOPP) \\
\hline $\begin{array}{c}\text { Aspirin with no history of coronary, cerebral or peripheral arterial occlusive } \\
\text { symptoms }\end{array}$ & 12 & 8 & 4 \\
\hline Calcium channel blockers with chronic constipation & 14 & 12 & 2 \\
\hline Non-cardioselective beta-blocker with chronic obstructive pulmonary disease & 39 & 30 & 9 \\
\hline $\begin{array}{l}\text { Use of aspirin and warfarin in combination without histamine } \mathrm{H} 2 \text { receptor } \\
\text { antagonist (except cimetidine because of interaction with warfarin) or proton pump } \\
\text { inhibitors }\end{array}$ & 5 & 4 & 1 \\
\hline Dipyridamole as monotherapy for cardiovascular secondary prevention & 6 & 4 & 2 \\
\hline Aspirin to treat dizziness not clearly attributable to cerebrovascular disease & 15 & 12 & 3 \\
\hline Phenothiazines in patients with epilepsy & 4 & 3 & 1 \\
\hline $\begin{array}{c}\begin{array}{c}\text { Diphenoxylate, loperamide or codeine phosphate for treatment of severe } \\
\text { gastroenteritis }\end{array}\end{array}$ & 5 & 4 & 1 \\
\hline $\begin{array}{l}\text { Selective alpha-blockers in males with frequent urinary incontinence, i.e. one or } \\
\text { more episodes of incontinence daily }\end{array}$ & 4 & 3 & 1 \\
\hline First-generation antihistamines in patients with falls & 12 & 10 & 2 \\
\hline Long-term opioids in patients with falls & 10 & 7 & 3 \\
\hline $\begin{array}{l}\text { Long-term opioids in those with dementia unless indicated for palliative care or } \\
\text { management of moderate/severe chronic pain syndrome }\end{array}$ & 4 & 3 & 1 \\
\hline Total & 130 & 100 & 30 \\
\hline
\end{tabular}

${ }^{*} \mathrm{PC}=$ Patient Counselling

*PC (STOPP $)=$ No. of patients avoided drugs 


\section{Journal of Cardiology \& Cardiovascular Therapy}

Table 9: Screening Tool to Alert doctors to Right Treatment.

\begin{tabular}{|c|c|c|c|}
\hline START & No. of Patients & PC (START) & Not PC(START) \\
\hline $\begin{array}{l}\text { Metformin with type } 2 \text { diabetes mellitus }+/- \text { metabolic syndrome (in the absence of renal } \\
\text { impairment, i.e. serum creatinine }>150 \mu \mathrm{mol} / \mathrm{l} \text {, or estimated GFR }<50 \mathrm{ml} / \mathrm{min} / 1.73 \mathrm{~m}^{2} \text { ) }\end{array}$ & 35 & 30 & 5 \\
\hline Calcium channel blockers with chronic constipation & 4 & 3 & 1 \\
\hline Aspirin for primary prevention of cardiovascular disease in diabetes mellitus & 30 & 27 & 3 \\
\hline Statin therapy for primary prevention of cardiovascular disease in diabetes mellitus & 18 & 15 & 4 \\
\hline $\begin{array}{l}\text { ACE inhibitor or angiotensin receptor blocker in diabetes with nephropathy i.e. overt urinalysis } \\
\text { proteinuria or micoralbuminuria ( }>30 \mathrm{mg} / 24 \text { hours) T serum biochemical renal impairment. } \\
\text { (Estimated } \mathrm{GFR}<50 \mathrm{ml} / \text { minute) }\end{array}$ & 5 & 4 & 1 \\
\hline Warfarin in the presence of chronic atrial fibrillation & 7 & 5 & 2 \\
\hline $\begin{array}{l}\text { Aspirin in the presence of chronic atrial fibrillation, where warfarin is contra-indicated, but not } \\
\text { aspirin }\end{array}$ & 4 & 3 & 1 \\
\hline $\begin{array}{l}\text { Aspirin or clopidogrel with a documented history of atherosclerotic coronary, cerebral or } \\
\text { peripheral vascular disease in patients with sinus rhythm }\end{array}$ & 3 & 2 & 1 \\
\hline Antihypertensive therapy where systolic blood pressure consistently > $160 \mathrm{mmHg}$ & 8 & 6 & 2 \\
\hline $\begin{array}{l}\text { Statin therapy with a documented history of coronary, cerebral or peripheral vascular disease, } \\
\text { where the patient's functional status remains independent for activities of daily living and life } \\
\text { expectancy is > } 5 \text { years }\end{array}$ & 4 & 3 & 1 \\
\hline Total & 118 & 97 & 21 \\
\hline
\end{tabular}

${ }^{*} \mathrm{PC}=$ Patient Counselling

${ }^{*} \mathrm{PC}(\mathrm{START})=$ No. of patients alerted drugs.

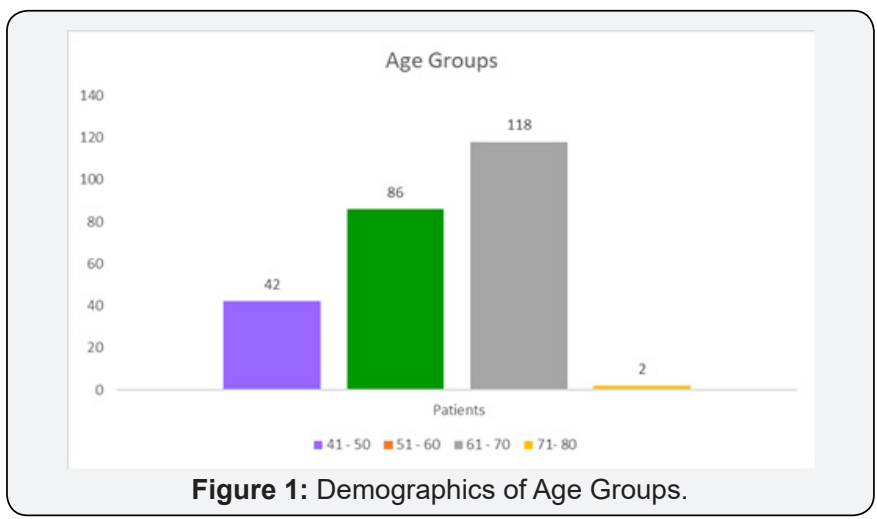

In our study we conclude the dose management for comorbid conditions were analysed and evaluated with the utilization of high-end prescribing drugs and other preferred therapies.

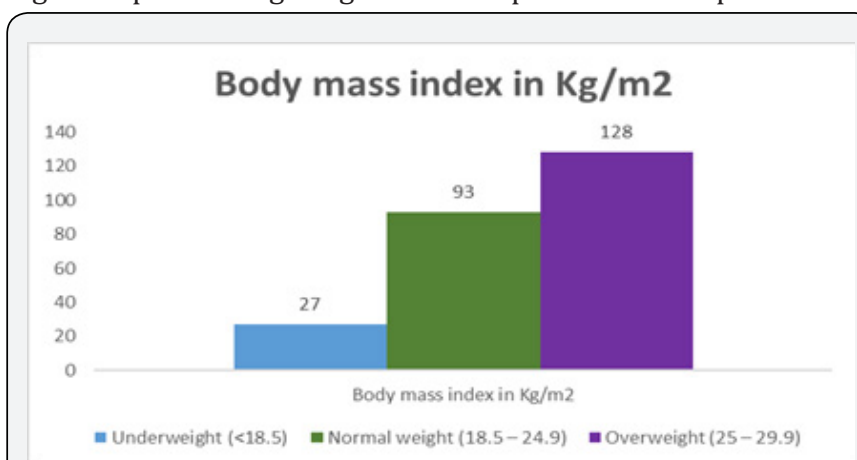

Figure 3: Demographics of Patient's Body mass index.

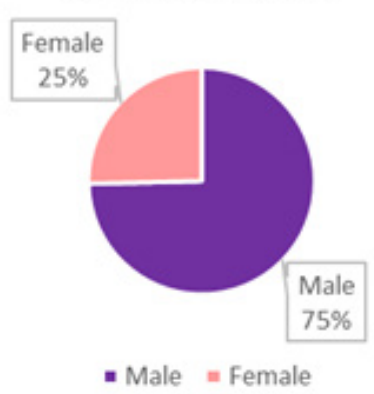

Figure 2: Demographics of Patient's Gender.

\section{Conclusion}

A total of 248 cases have been studied for the evaluation of the evaluated impact of clinical pharmacy services in care of patients with cardiovascular diseases. Commonest age range of the patients was 61-70 years. The incidence of cardiovascular diseases in 185 (75\%) were male and 63 (25\%) were female. 


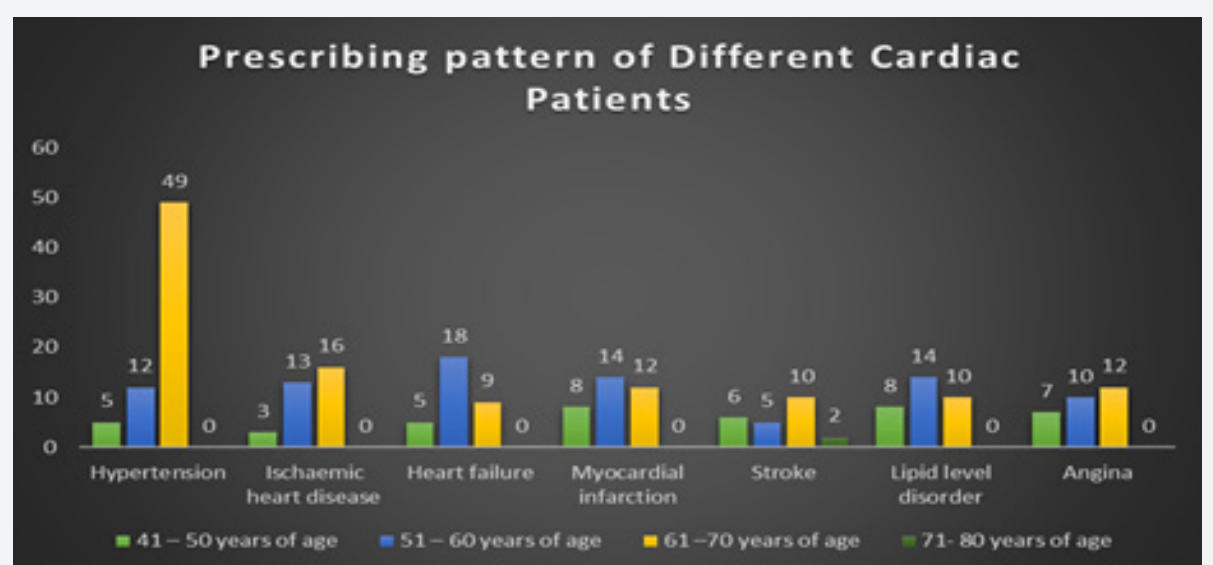

Figure 5: Grouping of prescriptions as per diseases and age.

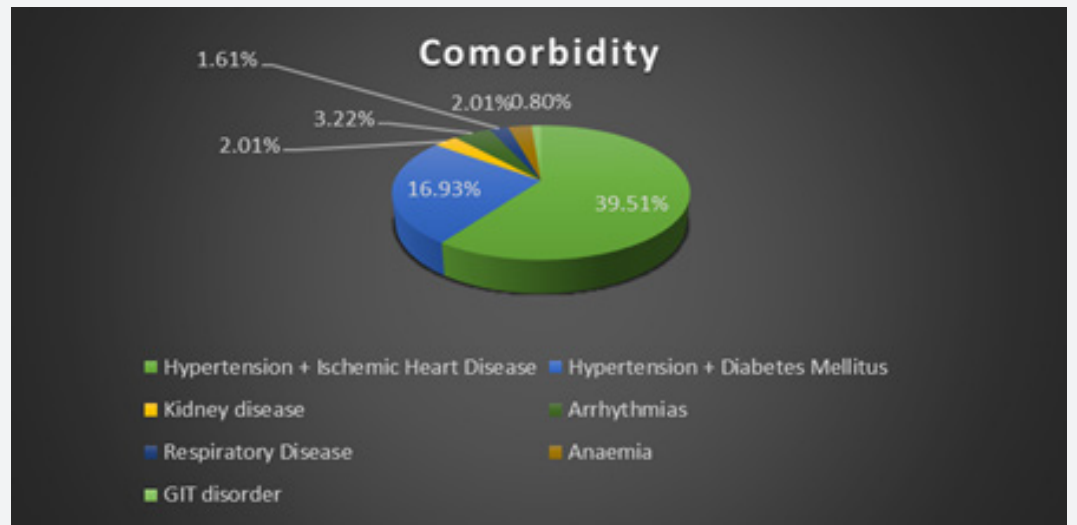

Figure 6: Comorbidity conditions.

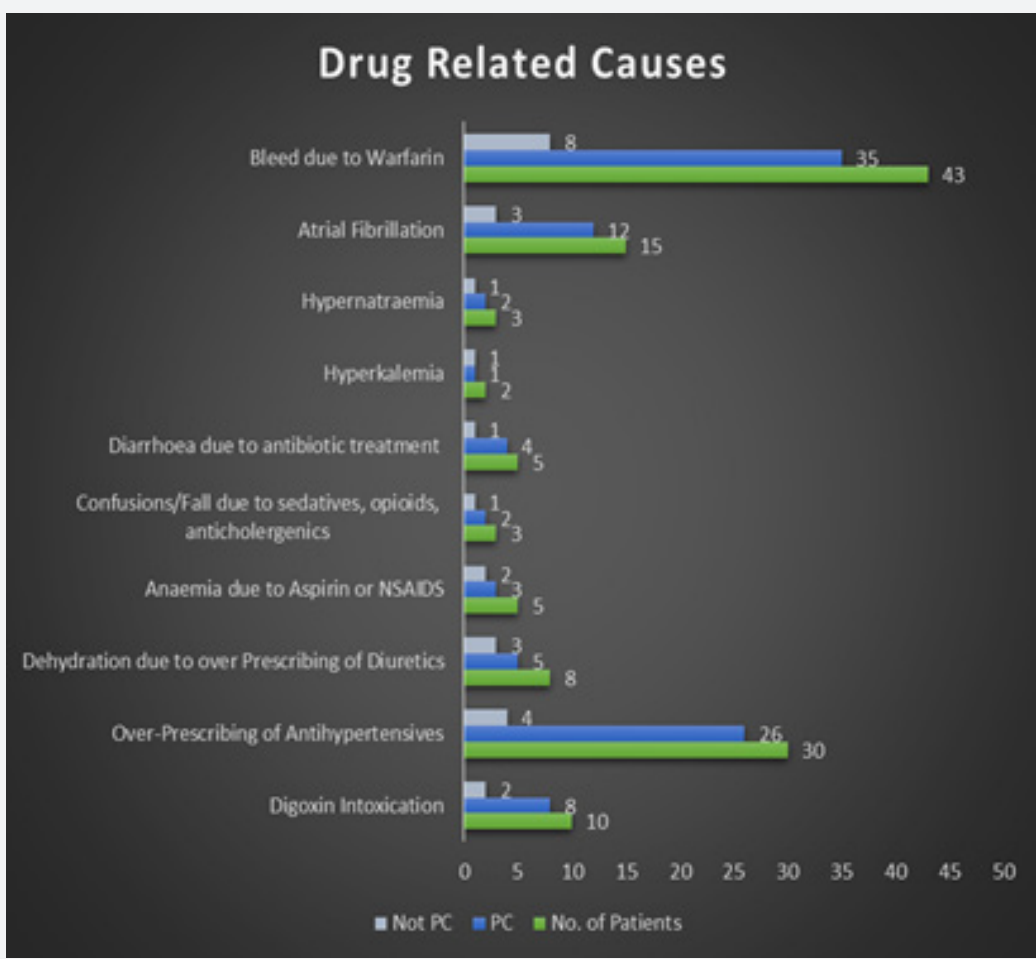

Figure 7: Drug Related Causes. 


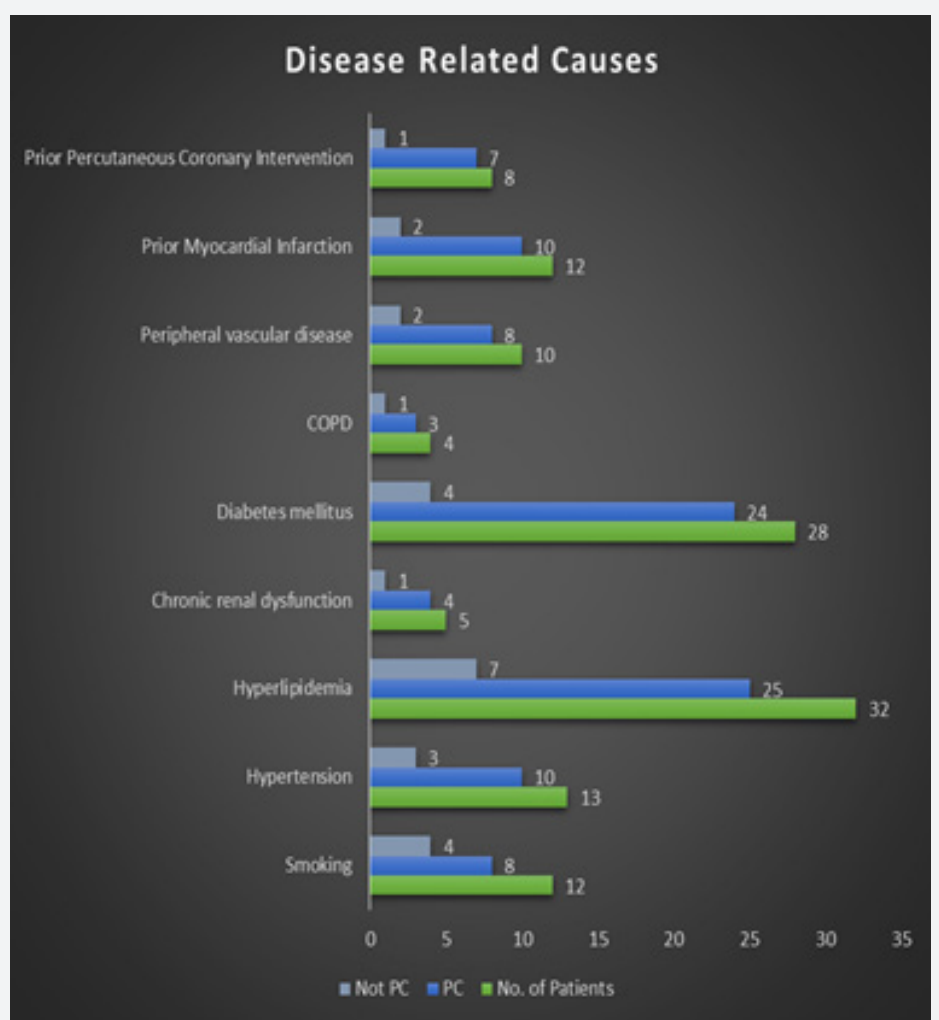

Figure 8: Disease Related Causes.

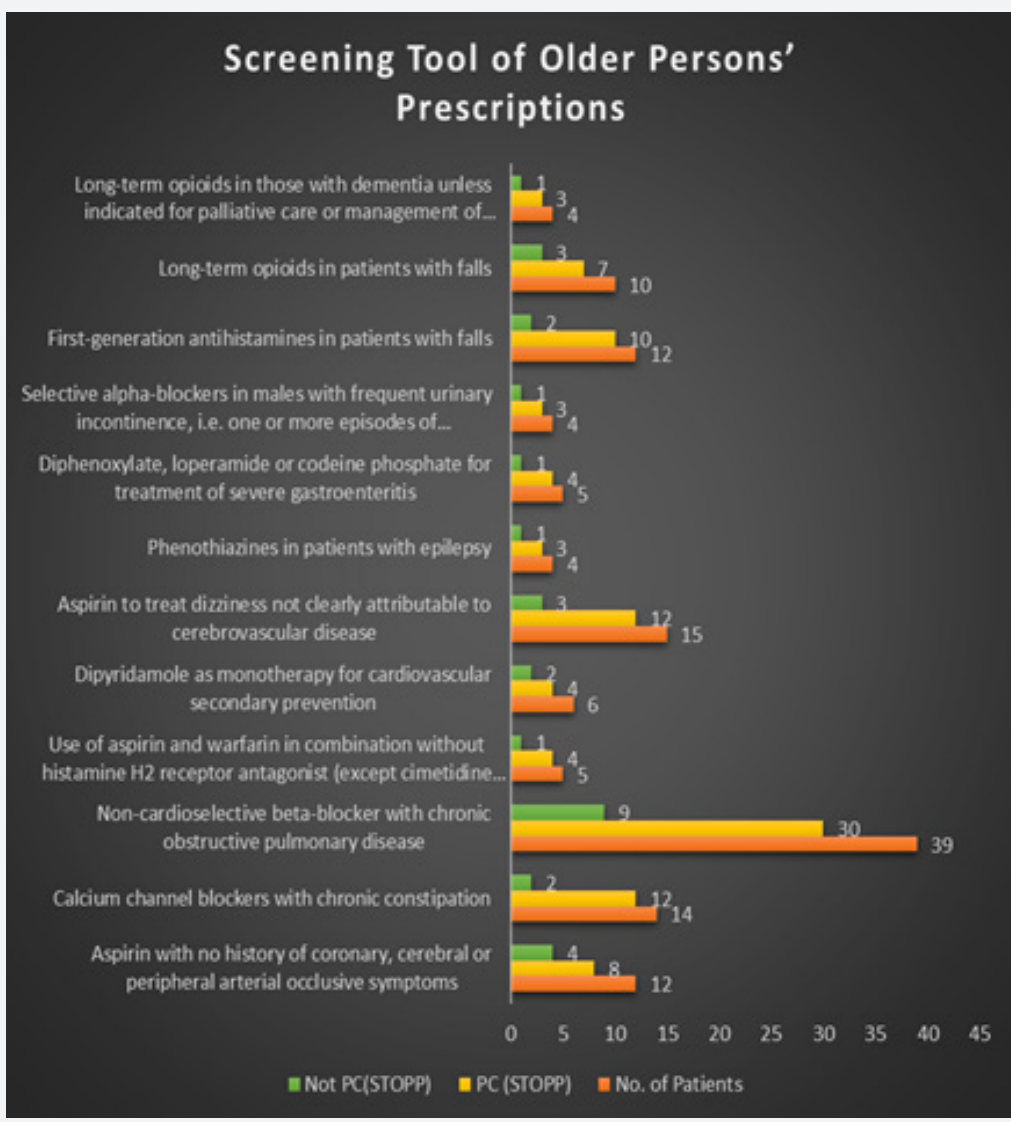

Figure 9: Screening Tool of Older Persons' Prescriptions. 


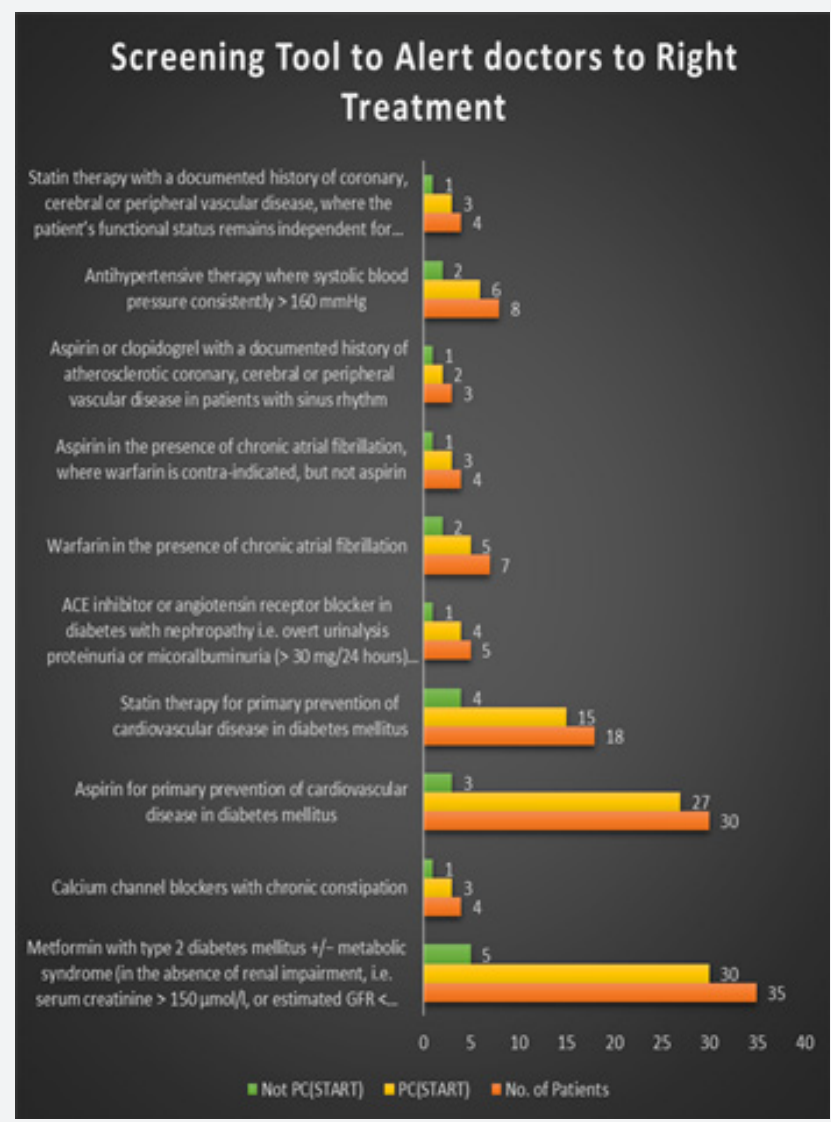

Figure 10: Screening Tool to Alert doctors to Right Treatment.

In Screening Tool of Older Persons' Prescriptions study 130 patients were prescribed with STOPP tool. Out of these 130 patients, 100 patients were in accordance with STOPP tool. The other 30 patients were not in accordance with STOPP.

In Screening Tool to Alert doctors to Right Treatment study 118 patients were prescribed with START tool. Out of these 118 patients, 97 patients were in accordance with START tool. The other 21 patients were not in accordance with START.

\section{References}

1. Beers MH, Ouslander JG, Rollingher I, Reuben DB, Brooks J, et al. (1991) Explicit criteria for determining inappropriate medication use in nursing home residents. UCLA Division of Geriatric Medicine. Arch Intern Med 151: 1825-1832.

2. Beers MH (1997) Explicit criteria for determining potentially inappropriate medication use by the elderly. An update. Arch Intern Med 157: 1531-1536.

3. Fick DM, Cooper JW, Wade WE, Waller JL, Maclean JR, et al. (2003) Updating the Beers criteria for potentially inappropriate medication use in older adults: results of a US consensus panel of experts. Arch Intern Med 163: 2716-2724.

4. O’Reilly V, Hartigan I, Coleman A, Morrissey C, O'Sullivan C et al. (2004) A new Screening Tool of Older Persons' Prescriptions (STOPP) in the acute hospital setting. Irish J Med Sci 173: 12-13.
5. Gallagher P, Ryan C, Byrne S, Kennedy J, O’Mahony D (2008) Screening Tool of Older Person's Prescriptions (STOPP) and Screening Tool to Alert doctors to Right Treatment (START). Consensus validation. Int J Clin Pharmacol Ther 46: 72-83.

6. Gallagher P, Baeyens JP, Topinkova E, Madlova P, Cherubini A, et al (2009) Inter-rater reliability of Screening Tool of Older Persons' Prescriptions (STOPP) and Screening Tool to Alert doctors to Right Treatment (START) criteria amongst physicians in six Euro- pean countries. Age Ageing 38: 603-606.

7. Ryan C, O'Mahony D, Byrne S (2009) Application of STOPP and START criteria: interrater reliability among pharmacists. Ann Pharmacother 43: 1239-1244.

8. Ryan C, O'Mahony D, Kennedy J, Weedle P, Byrne S (2009) Potentially inappropriate prescribing in an Irish elderly population in primary care. Br J Clin Pharmacol 68(6): 936-947.

9. Gallagher P, O'Mahony D (2008) Screening Tool of Older Persons' potentially inappropriate Prescriptions (STOPP): application to acutely ill elderly patients and comparison with Beers' criteria. Age Ageing 37: 673-679.

10. Byrne S, Ryan C, O’Mahony D, Weedle P, Kennedy J, et al. (2008) Inappropriate prescribing in the elderly: a review of primary care and nursing home pre- scriptions. In t J Pharm Pract Suppl 1: A36-A37. 

(C) This work is licensed under Creative

DOI: 10.19080/JOCCT.2019.13.555870
Your next submission with Juniper Publishers will reach you the below assets

- Quality Editorial service

- Swift Peer Review

- Reprints availability

- E-prints Service

- Manuscript Podcast for convenient understanding

- Global attainment for your research

- Manuscript accessibility in different formats

(Pdf, E-pub, Full Text, Audio)

- Unceasing customer service

Track the below URL for one-step submission https://juniperpublishers.com/online-submission.php 